Studia nad Autorytaryzmem i Totalitaryzmem 43, nr 2

Wrocław 2021

https://doi.org/10.19195/2300-7249.43.2.21

\author{
ALEKSANDER CIEŚLIŃSKI \\ ORCID: 0000-0001-7459-564X \\ Uniwersytet Wrocławski \\ aleksander.cieslinski@uwr.edu.pl
}

\title{
Europejski Trybunał Praw Człowieka wobec totalitarnej destrukcji porządku własnościowego w Polsce. Część 1
}

Słowa kluczowe: własność, reprywatyzacja, totalitarna destrukcja, Europejski Trybunał Praw Człowieka.

\author{
EUROPEAN COURT OF HUMAN RIGHTS AND THE TOTALITARIAN \\ DESTRUCTION OF PROPRIETARY ORDER IN POLAND. PART 1
}

\begin{abstract}
The aim of this article is to analyze the role of the European Court of Human Rights in overcoming totalitarian regime in the area of proprietary rights in Poland, the only state not adopting special legislation to meet these claims. It is the destruction of this part of the traditional legal system after World War II that can be considered as a key element of totalitarianism itself. However, this paper is not focused on historical developments, but rather on their current consequences, trying to evaluate links between them and modern legal order - particularly important in terms of limited temporal court jurisdiction over the area. In terms of the rule of law principle, it is essential how can a state cope with making good damages suffered by the victims. Careful research has proved practical application of the domestic law as well as functioning of public institutions to be based on serious systemic deficiencies making effective legal protection very difficult and sometimes impossible. They were rulings of the court playing a crucial role in supporting national authorities and setting standards of better protection - also achieved through judicial dialogue with the national judiciary. This very case-law also has a more general meaning, as it pictures a mode of ECHR's jurisdictional activity and quite functional approach to the interpretation of the convention.
\end{abstract}


This article is divided into two parts. The first one presents the general meaning of the area, the genesis of the protection, and major trends in the case-law development. The second part will offer a legal analysis of art. 1 and careful a systematization of leading rulings.

Keywords: property, reprivatization, totalitarian destruction, European Court of Human Rights.

\section{Wprowadzenie}

Europejski Trybunał Praw Człowieka powszechnie kojarzy się z ochroną klasycznych praw obywatelskich i politycznych, gdyż te zagadnienia dominują w Europejskiej Konwencji o Ochronie Praw Człowieka i Podstawowych Wolności ${ }^{1}$. Z pewnością jego orzecznictwo odegrało istotną rolę, nadając właściwe ramy transformacji państw Europy Środkowo-Wschodniej po upadku Związku Sowieckiego. Aktualizując wypracowane standardy, Trybunał wspierał systemy krajowe w przezwyciężaniu skutków działań reżimów totalitarnych po II wojnie światowej oraz przyczyniał się do zmian systemowych.

Nie zawsze jednak docenia się znaczenie, jakie w tym procesie odegrała ochrona prawa własności, a ten obszar nadawał się do tego szczególnie, chociażby ze względu na skalę dewastacji i piętno na tradycyjnym od pokoleń porządku, traktowanym jako ostoja egzystencji. W przeciwieństwie do naruszeń innych praw, zwłaszcza z najczarniejszego okresu lat czterdziestych i pięćdziesiątych XX wieku — nieodwracalnych, poza jurysdykcją Trybunału, których ofiary często nie mogły już przemówić w latach dziewięćdziesiątych, w tych sprawach sięganie do historii było relatywnie dostępne. Wynikało to ze swoistej międzypokoleniowej kontynuacji, pozwalającej nawet spadkobiercom kierować roszczenia już pod rządami Konwencji, choć pod pewnymi wymagającymi poniższej analizy warunkami. Chyba jedynymi porównywalnymi skargami, w których można było odwoływać się do tego rodzaju przeszłości, były takie jak rodzin katyńskich ${ }^{2}$ albo ojca zakatowanego Grzegorza Przemyka ${ }^{3}$. Jednakże tam punkt ciężkości musiano kłaść na współczesny sposób działania państwa i niezdolność osądzenia sprawców, a nie pierwotnie naruszenia — na przykład nietykalności czy życia. Także w sprawach majątkowych element ten jest kluczowy, jednak ochrona samego prawa własności wywodzonego sprzed dekad i bezprawnie odebranego nie została całkiem wykluczona.

Równocześnie przypadek III RP wydaje się godny specjalnej uwagi na tle innych państw, skoro ustawodawca po upadku PRL nie przyjął powszechnych regulacji reprywatyzacyjnych, czyniących zadość roszczeniom ofiar powojennych nacjonalizacji i wywłaszczeń. To zresztą rodzi reperkusje współcześnie, ze względu

${ }^{1}$ Dz.U. z 1993 r. Nr 61, poz. 284, dalej: Konwencja, Europejska Konwencja Praw Człowieka, EKPCz.

2 Janowiec i inni przeciwko Rosji - wyrok ETPCz z 21 października 2013 roku, skargi nr 555 08/07 i 29520/09.

3 Przemyk przeciwko Polsce — wyrok ETPCz z 17 września 2013 roku, skarga nr 22426/11. 
na złożoność procedur, także wykorzystywanych nieuczciwie, co choćby ostatnio zaowocowało pomysłem ostatecznego wygaszenia roszczeń, który w skrajnym ujęciu grozić może kolejną falą wieloletnich postępowań w Strasburgu. Stąd analizowana problematyka nie jest tylko zawieszona w zamkniętej historii rządów totalitarnych, a później autorytarnych, oraz utrwalonego i zamkniętego dorobku ETPCz i polskiej doktryny. Nawet jeżeli zmierzono się już z różnymi typami spraw i zarzutów, to nadal może pojawić się takie zaktualizowane wyzwanie, a generalnie materia pozostaje wciąż żywa i interesująca dla literatury ${ }^{4}$.

Dlatego warto pokazywać ogólniejsze znaczenie tej problematyki, które obok genezy i rozwoju ochrony orzeczniczej stanowić będzie przedmiot niniejszej części artykułu. Część druga przedstawi analizę postanowień konwencyjnych specyfikę interpretacji oraz strukturę, celem skonkretyzowania zakresu ochrony, a przede wszystkim autorską systematyzację przełomowych orzeczeń ze wskazaniem kluczowych elementów o takim znaczeniu.

\section{Znaczenie ogólne orzecznictwa w sprawach polskich}

Podejście do spraw własnościowych po upadku komunizmu w państwach takich jak Polska pozwala adekwatnie zdiagnozować wszelkie problemy przezwyciężania destrukcyjnych skutków tego ustroju. Jak w soczewce skumulowały się tutaj systemowe deficyty procesu transformacji obecne w sferze publicznej, zwłaszcza w procedurach administracyjnych i sądowych oraz szerzej w mechanizmach ochrony praw jednostek. Próby sprostania roszczeniom co do utraconego mienia ukazują zarazem ogólniejsze wyzwania realizacji praw człowieka, towarzyszące władzom krajowym w czasach przełomu, które nawet tu wykraczają poza wymiar ekonomiczny. Dotyczy to na przykład restytucji odbudowanych ze środków publicznych nieruchomości, zajmowanych od lat przez inne podmioty czy wypłat znacznych rekompensat z budżetu — tym trudniejsze do zaspokojenia w czasach kryzysu towarzyszącego początkom transformacji. W jeszcze szerszym ujęciu wiąże się to z koniecznością ważenia różnych dóbr i trudnych, także moralnie, wyborów w zakresie realizacji zobowiązań państwa, nawet wobec różnych ofiar totalitaryzmu.

Od samego Trybunału wymagało to wypracowania właściwego podejścia do kwestii granic swobody, jaką należało pozostawić władzom krajowym i właśnie w tych ramach kształtował się uniwersalniejszy, godny uwagi mechanizm współpracy z najwyższymi sądami krajowymi. Nie był on jedynie jednostronny, przyjmując raczej postać dialogu sądowego wzajemnie inspirujących się organów. To także w tym obszarze zdiagnozowano swoistą konstytucjonalizację systemu

${ }^{4}$ Zob. niedawno wydaną monografię: A. Mężykowska, Procesy reprywatyzacyjne $w$ państwach Europy Środkowo-Wschodniej a ochrona prawa własności w systemie Europejskiej Konwencji Praw Człowieka, Gdańsk 2019. 
konwencyjnego - wspierając nowe państwa w przejściu do praworządnego, chroniącego prawa człowieka ustroju, ETPCz nie mógł koncentrować się tylko na skargach indywidualnych, często bardzo wielu zawierających analogiczne zarzuty, lecz musiał sprostać wyzwaniom systemowym i strukturalnym ${ }^{5}$. Warto przypomnieć, że to dwie polskie sprawy własnościowe przyczyniły się do ostatecznego ukształtowania procedury wyroku pilotażowego - najpierw Broniowskiego ${ }^{6}$, a wkrótce potem Hutten-Czapskiej ${ }^{7}$. To umożliwiało ustanawianie standardów o powszechnym zastosowaniu, służących budowie skuteczniejszych mechanizmów ochrony - w tym wypadku prawa poszanowania mienia ${ }^{8}$.

Postępowania w przedmiotowym zakresie stanowiły zarazem jedno z pól doświadczalnych rozwoju strasburskiego modelu orzeczniczego, a zwłaszcza poszerzania granic jurysdykcji dzięki funkcjonalnej wykładni, nawet jeżeli polegało to na twórczym rozwinięciu wcześniejszego dorobku. Zastosowano ją już w kwestii zakresu czasowego Konwencji, aby właśnie skuteczniej chronić roszczenia własnościowe, mające źródło w przeszłości sprzed jej ratyfikacji — w kolejnych orzeczeniach niezbędne stało się usankcjonowanie konstrukcji spraw ciągłych. Co prawda już wcześniej Trybunał testował metody oceny tego, na ile odległe zdarzenia mogą mieć obecnie kontynuację ${ }^{9}$, jednak to upadek komunizmu i powszechny charakter tych roszczeń stanowił przełom w poszukiwaniu swoistej kontynuacji - zarówno w wymiarze materialnym, co do samego posiadania mienia, jak i proceduralnym, z uwzględnieniem specyfiki postepowań krajowych.

Zwiększanie zakresu skutecznej ochrony w tym obszarze stanowiło funkcję wykorzystania otwartego podejścia do pojęć konwencyjnych i struktury przepisów - istotnego dla całego systemu, począwszy od odpowiedniego ukształtowania rozumienia samego mienia wykraczającego poza cywilistyczną własność ${ }^{10}$. Nie mniej istotne okazało się obejmowanie zakresem kontroli nie tylko wyraźnie przewidzianego pozbawienia czy ograniczenia sposobu korzystania z niej, lecz

${ }^{5}$ W. Sadurski, Partnering with Strasbourg: Constitutionalisation of the European Court of Human Rights, the Accession of Central and East European States to the Council of Europe, and the Idea of Pilot Judgment, „Human Rights Law Review” 9, 2009, nr 3, s. 412.

${ }^{6}$ Broniowski przeciwko Polsce - wyrok ETPCz z 22 czerwca 2004 roku, skarga nr 31443/96, [w:] M.A. Nowicki, Nowy Europejski Trybunat Praw Człowieka. Wybór orzeczeń 1999-2004, Kraków 2005, s. 1224.

7 Hutten-Czapska przeciwko Polsce - wyrok ETPCz z 19 czerwca 2006 roku, skarga nr 350 14/97, [w:] M.A. Nowicki, Europejski Trybunat Praw Człowieka. Wybór orzeczeń 2006, Kraków 2007, s. 199.

${ }^{8}$ Co do specyfiki wyroków pilotażowych zob. J. Czepek, M. Lubiszewski, Procedura wyroku pilotażowego w praktyce Europejskiego Trybunału Praw Człowieka, Warszawa 2016.

${ }^{9} \mathrm{Na}$ przykład Loizidou przeciwko Turcji w zwiazku z inwazja Cypru przed uznaniem jurysdykcji ETPCz, wyrok ETPCz z 23 marca 1995 roku, skarga nr 15318/89.

10 I. Lach, Przedmiot ochrony prawa do własności w ujęciu Europejskiej Konwencji Praw Człowieka, „Studia Prawnicze” 2000, nr 3-4, s. 32; M.A. Nowicki, Wokół Konwencji Europejskiej. Komentarz do Europejskiej Konwencji Praw Człowieka, Warszawa 2017, s. 851-854; L. Garlicki, Komentarz do EKPC, t. 2, Warszawa 2011, s. 474. 
także mniej oczywistych ingerencji, wymykających się prostej kategoryzacji — również w powyższych sprawach polskich. Stało się to możliwe dzięki odejściu od traktowania pierwszego zdania art. 1, stanowiącego, że każdy ma prawo do poszanowania swego mienia, jako tylko zasady ogólnej, dopiero podlegającej konkretyzacji dalszymi postanowieniami szczególnymi, na rzecz uznania, że jest to samoistna podstawa weryfikacji działań państw ${ }^{11}$.

\section{Geneza ochrony własności}

Należy przypomnieć, że wśród twórców systemu Konwencji w latach czterdziestych nie było powszechnej zgody co do objęcia ochroną prawa własności, zwłaszcza że nie miała ona obejmować praw ekonomicznych, a obawiano się też żądań odszkodowań za popularne — nie tylko w bloku sowieckim — nacjonalizacje. Efektem była eliminacja dotyczących tego zapisów z przyjętego tekstu zasadniczego, ale ostatecznie jeszcze przed jego wejściem w życie prawo poszanowania mienia znalazło się w art. 1 Protokołu Dodatkowego I z 1953 roku. Zwyciężyło przekonanie co do jego wyjątkowego charakteru jako podstawy egzystencji, chociaż lewica krytykowała brak równoczesnego usankcjonowania praw socjalnych, na przykład prawa do pracy ${ }^{12}$.

Przez kolejne dekady orzecznictwo rozwijało się z pewnym opóźnieniem na tle innych praw, ale właśnie upadek komunizmu i objęcie nim nowych państw nadał stosowaniu tego artykułu nowy wymiar. Dotąd Trybunał najczęściej rozstrzygał incydentalne spory jednostek z państwami na tle wywłaszczeń czy ograniczeń, typowych dla praworządnych państw. Odtąd musiał stawić czoła efektom systemowej i planowej destrukcji ustroju, którego własność była fundamentem, opartej na niespotykanym bezprawiu i to w okresie zniszczeń substancji materialnej oraz nowych porządków terytorialnych. Wymagało to podejścia kompleksowego na tyle, aby objąć odległe, często złożone faktycznie i prawnie scenariusze w nowych okolicznościach historycznych, politycznych i socjalnych.

Wcześniejszy dorobek mógł oczywiście stanowić punkt wyjścia, ale nie był wystarczający ani do tych nowych wyzwań dostosowany. Inaczej musiało też wyglądać szukanie równowagi między wyzwaniami i potrzebami grup społecznych, zwłaszcza gdy naprawa dawnych nieprawości groziła nowymi i to w tych ramach

11 C. Warbrick, Law of the European Convention on Human Rights, Oxford 2009, s. 666; I. Nakielska, Prawo do własności w świetle Europejskiej Konwencji Praw Człowieka, Gdańsk 2002, s. 109-118; C. Mik, Ochrona prawa własności w prawie europejskim, [w:] O prawach człowieka. W podwójną rocznice Paktów. Księga pamiątkowa w hołdzie Profesor Annie Michalskiej, red. T. Jasudowicz, Toruń 1996, s. 438; B. Gronowska, Europejski Trybunał Praw Człowieka. W poszukiwaniu efektywnej ochrony praw jednostki, Toruń 2011, s. 177.

12 M. Nowicki, Wokót Konwencji..., s. 851; L. Garlicki, Komentarz..., s. 469; Z. Kulińska-Kępa, Prawa obywatelskie i polityczne a prawa gospodarcze, społeczne i kulturalne. Porównanie systemów ochrony, Warszawa 2017, s. 73-78. 
potrzebny był margines uznania władz krajowych. W praktyce pojawiły się dwie kategorie skarg, nie zawsze równie skuteczne. Próbowano kwestionować same wywłaszczenia i nacjonalizacje powojenne lub późniejsze, ale głownie chodziło o kontrolę rozwiązań restytucyjnych lub rekompensujących straty — już z okresu transformacji, ale i z rodowodem w poprzednim ustroju, ewentualnie nowelizowane ${ }^{13}$.

\section{Rozwój spraw polskich}

Polska przystąpiła do Protokołu I z rocznym opóźnieniem wobec uznania samej Konwencji, a więc 26 sierpnia 1994 roku. Polskie doświadczenia doby przeobrażeń i potrzeb rozliczenia się z totalitaryzmem oraz zadośćuczynienia ofiarom różnorodnych naruszeń dowodzą, że rozwiązywanie sporów własnościowych nie stanowiło priorytetu, a nawet budziło polityczną niechęć. Jednak brak uregulowań nie powodował ich uśmierzania, zwiększając tylko potencjał skarg do ETPCz. Dlatego jeżeli obecnie planuje się ostatecznie zablokować roszczenia reprywatyzacyjne, warto dokładać starań umiejętnego wyważenia potrzeb bezpieczeństwa prawnego z zachowaniem szans na rzetelny proces sądowy, aby uniknąć kolejnej ich fali.

Celem tego punktu jest nakreślenie głównych trendów rozwoju orzecznictwa w sprawach polskich w kontekście historycznym, aby uchwycić kluczowe problemy, co będzie podstawą systematyzacji wyroków i ich analizy prawnej w części drugiej artykułu. Na początek jednak warto zwrócić uwagę na wyzwanie dla ETPCz, jakim stało się zjednoczenie Niemiec, gdyż przyjęty w tych ramach standard stosowania art. 1 do dzisiaj stanowi punkt odniesienia dla różnych rozstrzygnięć reprywatyzacyjnych w wielu państwach ${ }^{14}$. Wyzwanie to determinował kontekst geopolityczny, związany z powojennym podziałem Niemiec, a wynikający oczywiście z nazistowskiego totalitaryzmu. Ale już kształt powojennych państw, zwłaszcza tego wschodniego i jego ustroju dewastującego własność, to owoc działania tego samego sowieckiego totalitaryzmu, którego ofiarami stały się państwa i obywatele regionu, co wymagało przezwyciężenia po latach, kiedy terytorium byłej NRD poddano systemowi prawnemu RFN.

13 L. Garlicki, Transformacja ustrojowa a ochrona prawa własności (aktualne tendencje w orzecznictwie ETPCz), [w:] Ratio est anima legis. Księga jubileuszowa ku czci Profesora Janusza Trzcińskiego, red. J. Góral, Warszawa 2007, s. 386.

14 Jahn i inni przeciwko Niemcom - wyrok ETPCz z 22 stycznia 2004 roku, skargi nr 46720/99, 72203/01 i 72552/01, [w:] M.A. Nowicki, Nowy Europejski Trybunat..., s. 1221; A. Nußberger, Wtasność, która się ,nie należy”. Kontrowersyjne orzeczenia sądowe Federalnego Trybunału Konstytucyjnego i Europejskiego Trybunatu Praw Człowieka dotyczące wywłaszczeń bez odszkodowania w procesie zjednoczenia Niemiec, [w:] Własność - zagadnienia ustrojowo-prawne. Porównanie rozwiązań w państwach Europy Środkowo-Wschodniej, red. K. Skotnicki, Łódź 2006, s. 243 n. 
Zaryzykować można natomiast tezę, że im bardziej ów kontekst geopolityczny obecny jest bezpośrednio $\mathrm{w}$ danej sprawie, tym pełniej pozwala ona ukazać skutki tego reżimu w ich całokształcie. Warto bowiem uwzględnić znaczenie, jakie dla sytuacji właścicieli miał rosyjski imperializm, wykorzystujący instrumenty komunistycznego porządku dla ekspansji terytorialnej - wymuszonej na Polsce, formalnie za zgodą pozostałych mocarstw. Ten wymiar totalitaryzmu odcisnął dodatkowe piętno na porządku własnościowym w Polsce, poza narzuceniem ustroju gwałcącego zasady gospodarki rynkowej o tak drastycznych skutkach dla poszanowania mienia. Wywoływało to reperkusje jeszcze długo po upadku PRL, wymagając adekwatnego standardu orzeczniczego, i dlatego warto wyodrębnić związaną z tym kategorię spraw, a nawet potraktować ją priorytetowo, zwłaszcza że w tych ramach zainicjowano wyroki pilotażowe w obliczu roszczeń około 80 tysięcy tak zwanych Zabużan.

Historyczna kumulacja czynników miała bowiem istotny wpływ na sytuację obywateli II RP i ich spadkobierców dysponujących majątkami często od pokoleń na ziemiach przejętych przez Związek Sowiecki. Były one dotkliwsze niż dla właścicieli w nowych granicach, nawet mocno pokrzywdzonych nowym ustrojem i naruszaniem ówczesnego prawa. Ponad milion Polaków de facto wypędzono na warunkach państwa totalitarnego, wymuszając porzucenie całego dobytku, którego nie dało się zabrać, i w sposób nieodwracalny pozbawiając prawa własności, zwłaszcza nieruchomości, w tym nawet dostępu do nich. O ile skargi tej kategorii, kierowane już wkrótce po uznaniu jurysdykcji ETPCz, nie dotyczyły par excellence reprywatyzacji, to jednak adekwatnie oddają sposób, w jaki reżim totalitarny obszedł się z właścicielami w ogóle, a niepodległe już państwo potraktowało roszczenia będące następstwem utraty własności. Chodzi więc zarówno o czasy PRL, jak i okres po 1989 roku, uznawany za przywracający system poszanowania praw człowieka, kiedy uzewnętrzniły się wspomniane wyzwania transformacji. W tym sensie orzecznictwo zabużańskie dotykało problemów wspólnych dla innych postepowań „reprywatyzacyjnych”, stając się symptomatyczne w ogólniejszym wymiarze.

Jest jeszcze jeden aspekt wyróżniający te sprawy, zwłaszcza w kontekście braku ustawy reprywatyzacyjnej, gdyż tutaj podstawę dochodzenia roszczeń z tytułu utraconego mienia stworzono - $\mathrm{i}$ to jeszcze o charakterze międzynarodowoprawnym - jako traktatowy element relacji geopolitycznych. Były to tak zwane umowy republikańskie zawarte w 1944 roku między PKWN, marionetkowym organem władzy wykonawczej, a Socjalistycznymi Republikami Rad: Ukraińską, Białoruską i Litewską, w których państwo polskie przejęło odpowiedzialność za rekompensowanie strat z tytułu tych majątków. Nawet jeżeli upodobniało to sytuację do rozwiązań innych krajów, to jednak nie zapewniało automatycznego, pełnego zaspokojenia roszczeń, gdyż dla skuteczności w indywidualnych sprawach niezbędne było przyjęcie regulacji krajowych. Pojawiły się one już w latach 
czterdziestych, aby ulegać zmianom, na tyle niedoskonałym, że doprowadziły do wyroku $\mathrm{ETPCz}^{15}$.

Takiego systemowo interesującego rozwiązania zabrakło w eliminacji niemieckiego totalitaryzmu po rozciągnięciu polskiego zwierzchnictwa nad ziemiami zachodnimi i północnymi, co próbowało wykorzystać Pruskie Powiernictwo jako swoistą próżnię prawną, sugerując brak nieodwracalnego wykluczenia roszczeń tak zwanych wypędzonych. Trybunał zablokował to w 2008 roku ze względu na oczywistą niedopuszczalność, ostatecznie obciążając Niemcy odpowiedzialnością także za majątkowe konsekwencje zmian granic i wykluczając roszczenia wobec Rzeczypospolitej ${ }^{16}$.

Innym charakterystycznym obszarem, który przyczynił się do rozwoju orzecznictwa stały się tak zwane grunty warszawskie. Sam radyklany sposób uregulowania specjalnym dekretem tego wycinka nieruchomości w mieście stołecznym, jak i późniejszy model praktycznego wykonania, urągający praworząaności, można uznać za kwintesencję totalitarnej destrukcji porządku własnościowego. Państwo z mocy prawa odebrało je prawowitym właścicielom, zastrzegając tylko możliwość wnioskowania o prawo wieczystej dzierżawy, zabudowy lub nieruchomości zastępczej, które w praktyce często załatwiano odmownie, nie rozpatrywano, nie doręczając decyzji. Nie lepiej było z roszczeniami odszkodowawczymi, gdzie przewidziano krótki termin, aby jeszcze za PRL je wygasić, niezależnie od indywidualnych okoliczności ${ }^{17}$.

Co istotne, pewne cele tych rozwiązań, a nawet ich racjonalne stosowanie, broniłyby się w wyjątkowych powojennych okolicznościach zniszczeń, zwłaszcza że nacjonalizacje nie były jedynie domeną państw komunistycznych. Standard konwencyjny też ich nie wykluczył. Ale akurat przyjęte gwarancje ochrony mogące ucywilizować proces często pozostawały martwą literą. A dochodząca do tego praktyka tak zwanej dzikiej reprywatyzacji stała się symbolem niewydolności systemu instytucjonalno-prawnego państwa postkomunistycznej transformacji.

Jednakże ponieważ ograniczenia zakresu czasowego stosowania Konwencji wobec Polski często wykluczały jurysdykcję wobec czystych roszczeń własnościowych, w orzecznictwie ukształtował się równoległy trend w sprawach byłych właścicieli, pozwalający kontrolować państwo niekoniecznie na podstawie art. 1 Protokołu I. O ile bowiem mienie utracono bezpowrotnie w reżimie totalitarnym,

15 P. Filipek, The 1944 "Republican Agreements" and the compensation for "property left beyond the Bug River": reaching a definite settlement after 60 years? „The Polish Yearbook of International Law" 2004-2005, s. 27.

16 Preussische Treuhand GMBH and CO. KG. A.A. przeciwko Polsce, [w:] M. KrzyżanowskaMierzewska, Skarga Powiernictwa Pruskiego. Glosa do decyzji ETPC z dnia 7 października 2008 r., 47550/06, „Europejski Przegląd Sądowy” 2009, nr 2, s. 44- 47.

17 Dekret z 26 października 1945 roku o własności i użytkowaniu gruntów na obszarze miasta stołecznego Warszawy (Dz.U. z 1945 r. Nr 50, poz. 279 ze zm.), wydany na podstawie ustawy z 3 stycznia 1945 roku o trybie wydawania dekretów z mocą ustawy (Dz.U. z 1945 r. Nr 1, poz. 1); Ł. Bernatowicz, Reprywatyzacja na przykładzie gruntów warszawskich, Warszawa 2015, passim. 
to ich postępowania toczyły się już pod rządami EKPCz. To właśnie ich ,jakość”, a więc przekroczenie dopuszczalnych granic przewlekłości w rozumieniu art. 6 Konwencji, stawała się pierwszoplanowa i na tej podstawie rozstrzygał Trybunał, rezygnując czasem nawet $\mathrm{z}$ analiz materialnoprawnych, co wystarczało jednak do jakiegoś zadośćuczynienia ofiarom totalitarnych rządów ${ }^{18}$.

\section{Bibliografia}

Bernatowicz Ł., Reprywatyzacja na przykladzie gruntów warszawskich, Warszawa 2015.

Czepek J., Lubiszewski M., Procedura wyroku pilotażowego w praktyce Europejskiego Trybunału Praw Człowieka, Warszawa 2016.

Filipek P., The 1944 "Republican Agreements" and the compensation for "property left beyond the Bug River”: reaching a definite settlement after 60 years? „The Polish Yearbook of International Law" 2004-2005.

Garlicki L., Komentarz do EKPC, t. 2, Warszawa 2011.

Garlicki L., Transformacja ustrojowa a ochrona prawa wtasności (aktualne tendencje w orzecznictwie ETPCz), [w:] Ratio est anima legis. Księga jubileuszowa ku czci Profesora Janusza Trzcińskiego, red. J. Góral, Warszawa 2007.

Gronowska B., Europejski Trybunat Praw Człowieka. W poszukiwaniu efektywnej ochrony praw jednostki, Toruń 2011.

Jarosz-Żukowska S., Właściwość Europejskiego Trybunału Praw Człowieka w sprawach dawnych aktów nacjonalizacyjnych $i$ wywłaszczeniowych oraz nowego ustawodawstwa restytucyjnego — sprawy polskie, „Wrocławskie Studia Erazmiańskie” 2009.

Krzyżanowska-Mierzewska M., Skarga Powiernictwa Pruskiego. Glosa do decyzji ETPC z dnia 7 października 2008 r., 47550/06, „Europejski Przegląd Sądowy” 2009, nr 2.

Kulińska-Kępa Z., Prawa obywatelskie i polityczne a prawa gospodarcze, społeczne i kulturalne. Porównanie systemów ochrony, Warszawa 2017.

Lach I., Przedmiot ochrony prawa do własności w ujęciu Europejskiej Konwencji Praw Człowieka, „Studia Prawnicze” 2000, nr 3-4.

Mężykowska A., Procesy reprywatyzacyjne w państwach Europy Środkowo-Wschodniej a ochrona prawa własności w systemie Europejskiej Konwencji Praw Człowieka, Gdańsk 2019.

Mik C., Ochrona prawa własności w prawie europejskim, [w:] O prawach człowieka. W podwójna rocznice Paktów. Księga pamiątkowa w hołdzie Profesor Annie Michalskiej, red. T. Jasudowicz, Toruń 1996.

Nakielska I., Prawo do własności w świetle Europejskiej Konwencji Praw Człowieka, Gdańsk 2002.

Nakielska I., ,Mienie zabużańskie” $i$,grunty warszawskie” w polskich sprawach przed Europejskim Trybunałem Praw Człowieka, „Gdańskie Studia Prawnicze” 14, 2005.

Nowicki M.A., Nowy Europejski Trybunat Praw Człowieka. Wybór orzeczeń 1999-2004, Kraków 2005.

Nowicki M.A., Europejski Trybunat Praw Człowieka. Wybór orzeczeń 2006, Kraków 2007.

18 I. Nakielska, „Mienie zabużańskie” i ,,grunty warszawskie” w polskich sprawach przed Europejskim Trybunałem Praw Człowieka, „Gdańskie Studia Prawnicze” 14, 2005, s. 131-132; S. Jarosz-Żukowska, Właściwość Europejskiego Trybunału Praw Człowieka w sprawach dawnych aktów nacjonalizacyjnych $i$ wywlaszczeniowych oraz nowego ustawodawstwa restytucyjnego sprawy polskie, „Wrocławskie Studia Erazmiańskie” 2009, s. 205-207; Beller przeciwko Polsce, skarga nr 51837/99; Sierpiński przeciwko Polsce, skarga nr. 38016/07, [w:] D. Sześciło, Glosa do wyroku ETPC z dnia 3 listopada 2009 r., 38016/07, „Samorząd Terytorialny” 7-8, 2010, s. 171-174. 
Nowicki M.A., Wokót Konwencji Europejskiej. Komentarz do Europejskiej Konwencji Praw Człowieka, Warszawa 2017.

Nußberger A., Własność, która się „nie należy”. Kontrowersyjne orzeczenia sądowe Federalnego Trybunału Konstytucyjnego i Europejskiego Trybunału Praw Człowieka dotyczace wywłaszczeń bez odszkodowania w procesie zjednoczenia Niemiec, [w:] Własność — zagadnienia ustrojowo-prawne. Porównanie rozwiązań w państwach Europy Środkowo-Wschodniej, red. K. Skotnicki, Łódź 2006.

Sadurski W., Partnering with Strasbourg: Constitutionalisation of the European Court of Human Rights, the Accession of Central and East European States to the Council of Europe, and the Idea of Pilot Judgment, „Human Rights Law Review” 9, 2009, nr 3.

Sześciło D., Glosa do wyroku ETPC z dnia 3 listopada 2009 r., 38016/07, „Samorząd Terytorialny” 7-8, 2010.

Warbrick C., Law of the European Convention on Human Rights, Oxford 2009. 